\title{
PENINGKATAN KUALITAS PELAYANAN BADAN USAHA MILIK DESA MELALUI PELATIHAN ADMINISTRASI PROGRAM SIMPAN PINJAM DI SELEBUNG BATUKLIANG LOMBOK TENGAH
}

\author{
Ibrahim $^{1 *}$, Mas, $\mathbf{a d}^{2}$, Kamaluddin $^{3}$, Achmad Djunaidi $^{4}$ \\ ${ }^{1 *}$ Program Studi Pendidikan Geografi, Fakultas Keguruan dan IImu Pendidikan, Universitas Muhammadiyah Mataram \\ 2Program Studi Pendidikan Geografi, Fakultas Keguruan dan Ilmu Pendidikan, Universitas Muhammadiyah Mataram \\ ${ }^{3}$ Program Studi Pendidikan Geografi, Fakultas Keguruan dan Ilmu Pendidikan, Universitas Muhammadiyah Mataram \\ ${ }^{4}$ Program Studi Pendidikan Geografi, Fakultas Keguruan dan IImu Pendidikan, Universitas Muhammadiyah Mataram

$$
\text { E-mail: ibrahimali.geo@gmail.com }
$$$$
{ }^{*} \text { Corresponding author : }
$$

Diterima 30 April 2018, Disetujui 4 Mei 2018

\begin{abstract}
ABSTRAK
Badan Usaha Milik Desa (BUMDes) memiliki peranan penting dalam meningkatkan kesejahteraan masyarakat perdesaan. Keberadaan BUMDes terutama program simpan pinjam memberikan nilai lebih dalam memberikan peluang akses lebih cepat dan mudah dalam meminjamkan uang sebagai modal usaha. Tujuan penelitian ini adalah untuk mengetahui kualitas pelayanan badan usaha milik desa melalui pelatihan administrasi program simpan pinjam pada Desa Selebung Batukliang Lombok Tengah. Metode Penelitian menggunakan pendekatan deskriptif kualitatif. Pengumpulan data menggunakan wawancara mendalam dengan pihak desa, pengelola BUMDes dan masyarakat penerima manfaat program. Analisis data dalam penelitian ini menggunakan model analisis interaktif yaitu analisis dengan menggunakan reduksi data, display data, dan verifikasi dan kesimpulan. Hasil penelitian ini menemukan bahwa keberadaan pelatihan administrasi pada program simpan pinjam memberikan dampak positif dalam pengembangan usaha. Hal ini dibuktikan dari sebelumnya pengolahan admnistrasi masih bersifat administrasi manual dan berubah menggunakan komputerisasi dengan sistem yang teratur.
\end{abstract}

Kata Kunci: Pelayanan, BUMDes dan Simpan Pinjam

\begin{abstract}
Village Owned Enterprises (BUMDes) have an important role in improving the welfare of rural communities. The existence of BUMDes, especially savings and loans programs provide more value in providing access opportunities more quickly and easily in lending money as venture capital. The purpose of this study is to determine the quality of services owned by village enterprises through training administration of savings and loan program in SelebungBatukliang Village Lombok Tengah. The research method used qualitative descriptive approach. Data collection used in-depth interviews with villagers, BUMDes managers and beneficiary communities. Data analysis in this research using interactive analysis model that is analysis by using data reduction, data display, and verification and conclusion. The results of this study found that the existence of administrative training on savings and loan programs provide a positive impact in business development. This is evidenced from the previous administrative processing is still a manual administration and changed using computerized with a regular system.
\end{abstract}

Keywords : Service, BUMDes and Simpan Pinjam

PENDAHULUAN

Pembangunan nasional dalam UndangUndang Dasar 1945 menitikberatkan pada masyarakat adil yang makmur. Pembangunan secara umum senantiasa menciptakan keselarasan dan keseimbangan dalam hidupnya, baik secara rohani dan jasmani. Pembangunan nasional sebagai upaya untuk meningkatkan seluruh aspek kehidupan masyarakat, bangsa dan negara yang sekaligus merupakan proses pengembangan keseluruhan sistem penyelenggaraan negara untuk mewujudka ntujuan nasional.

Untuk mencapai tujuan pembangunan secara adil dan merata bagi seluruh rakyat 
Indonesia. Nugroho dan Rochmin Danuri (2004) menjelaskan bahwa perlukan adanya suatu upaya terkoordinasi untuk menciptakan alternatif yang lebih banyak secara sah kepada setiap warga negara untuk memenuhi dan mencapai aspirasinya yang paling manusiawi.

Undang-Undang No. 32 tahun 2004 tentang otonomi daerah menitikberatkan otonomi daerah pada kabupaten. Namun dengan diberlakukan Undang-Undang No. 6 Tahun 2014 tentang desa. Otonomi terluas dan terdekat dengan masyarakat memiliki arti otonomi desa akan mampu memiliki inisiatif dengan berkreatifitas untuk menjalankan roda pemerintahan sendiri. Desa memiliki ruang gerak yang luas dalam melaksanakan pembangunan dan tidak terbebani dengan program pembangunan dari provinsi dan kabupaten.

Pembangunan desa memiliki menitikberatkan pada kemampuan meningkatkan kesejahteraan masyarakat melalui program dan pelayanan pada masyarakat. Pelayanan desa pada masyarakat termasuk dalam kategori rendah. Hasil penelitian Sari (2015) menilai bahwa persepsi msyarakat terhadap kinerja aparatur desa dalam meningkatkan pelayanan publik antara lain: 1) pemahaman masyarakat dengan persentase $73,33 \%$ dalam kategori kurang paham, 2) tanggapan masyarakat dengan persentase $73,34 \%$ dalam kategori negatif, 3) harapan masyarakat dengan persentase $53,33 \%$ dalam kategori positif. Berdasarkan ketiga indikator bahwa pelayanan publik dalam hal pelayanan reguler belum maksimal dan belumberjalan secara optimal.

Pelayanan yang rendah dapat memberikan dampak bagi pelayanan pada masyarakat. Desa memiliki banyak potensi tidak hanya dari segi jumlah penduduk, tetapi juga ketersediaan sumber daya alam yang melimpah. Jika kedua potensi ini bisa dikelola dengan maksimal maka akan memberikan kesejahteraan bagi penduduk desa. Akan tetapi, disadari bahwa selama ini pembangunan pada tingkat desa masih memiliki banyak kelemahan (Prasetyo, 2016).

Kelemahan pembangunan pada tingkat desa antara lain disebabkan tidak hanya karena persoalan sumber daya manusia yang kurang berkualitas tetapi juga disebabkan karena persoalan keuangan. Berbagai upaya telah dilakukan pemerintah dengan menggelontorkan berbagai dana untuk program pembangunan desa yang salah satunya adalah melalui Badan Usaha Milik Desa (BUMDes).

Keberadaan BUMDes belum mampu memberikan manfaat karena memiliki kendala dalam pelaksanaan. Hasil penelitian Susanti dan Ardana (2016) menjelaskan bahwa BUMDES memberikan pelayanan Unit Usaha Simpan Pinjam, Unit Usaha Perdagangan, Unit Usaha Ternak dan Unit Usaha Air Bersih/ UPS kepada masyarakat dan sudah berjalan baik, namun memiliki kendala yang dihadapi dalam pengembangan BUMDes adalah kurangnya sarana dan prasarana dan kurang memahaminya masyarakat tentang BUMDes.

Kendala yang dihadapi diatas diperkuat dari hasil penelitian Prasetyo (2016) Hasil dari penelitian menunjukkan bahwa partisipasi masyarakat dalam kegiatan BUMDes masih kurang karena pengetahuan masyarakat terhadap program BUMDes masih sedikit. Terkait pola pemanfaatan lebih banyak pada pembangunan fisik desa sedangkan kontribusi bagi pemberdayaan masyarakat masih belum maksimal karena sejumlah kendala terutama yaitu anggaran BUMDes.

Hal ini diperkuat dari hasil penelitian Ibrahim dkk (2017) menyatakan bahwa Persebaran program BUMDes di Kabupaten Sumbawa Barat dapat lebih fokus pada program simpan pinjam dibandingkan dengan program lainnya. Program ini belum optimal karena masih rendahnya Sumberdaya Manusia dan enterpreneurshif dan perlu adanya pelatihan pendukung, guna meningkatkan tata kelola BUMDes secara berkelanjutan.

Undang-Undang Nomor 6 tahun 2014 tentang Desa dalam Pasal 89 Badan Usaha Milik Desa adalah badan usaha yang seluruh atau sebagian besar modalnya dimiliki oleh desa melalui penyertaan secara langsung yang berasal dari kekayaan desa yang dipisahkan guna mengelola aset, jasa pelayanan, dan usaha lainnya untuk sebesarbesarnya kesejahteraan masyarakat Desa. Hasil usaha Badan Usaha Milik Desa dimanfaatkan untuk: 1) Pengembangan usaha; dan 2) Pembangunan desa, pemberdayaan masyarakat desa, dan pemberian bantuan untuk masyarakat miskin melalui hibah, bantuan sosial, dan kegiatan dana bergulir yang ditetapkan dalam Anggaran Pendapatan dan Belanja Desa.

Desa Selebung merupakan salah satu desa dari 10 desa yang ada di wilayah Kecamatan Batukliang Kabupaten Lombok Tengah, yang merupakan desa pemekaran dari Desa Teratak Berawal dari keinginan masyarakat yang mengharapkan peningkatan kwalitas pelayanan publik mengingat pusat pemerintahan desa induk (Teratak) jaraknya cukup jauh sekitar $2 \mathrm{~km}$ dari Dusun Selebung. Jumlah penduduk Desa Selebung pada tahun 2017 adalah 8.835 Jiwa yang terdiri dari 
jumlah penduduk laki-laki 4.412 Jiwa dan jumlah penduduk wanita 4.423 Jiwa. Dilihat dari mata pencaharian, sebagian besar penduduk Desa Selebung bermata pencaharian sebagai petani pemilik sebanyak 704 orang, dan buruh tani 892 Orang orang. Masyarakat yang lainnya bermata pencaharian sebagai wiraswasta sebanyak 774 orang dan sebagian kecil sebagai PNS 62 orang, Peternak 34 orang.

BUMDes Desa Selebung didirikan dengan tujuan adalah: 1) Meningkatkan pendapatan asli desa dalam rangka meningkatkan kemampuan pemerintah desa dalam penyelenggaraan pemerintahan dan pembangunan serta pelayanan masyarakat; 2) Mengembangkan potensi perekonomian di wilayah pedesaan untuk mendorong tumbuhnya usaha perekoniman masyarakat desa secara keseluruhan dalam rangka pengentasan kemiskinan; dan 3) Menciptakan Lapangan Kerja, Penyediaan dan jaminan Sosial.

Tujuan pembentukan Badan Usaha Milik Desa pada Desa Selebung dapat memberikan pelayanan kepada masyarakat, khususnya masyarakat miskin, untuk memberdayakan diri keluar dari belenggu kemiskinan. Di sisi lain, BUMDes Desa Selebung dituntut tidak hanya memenuhi tujuan imateriil (ideal), tetapi juga dituntut untuk mencapai tujuan materiil, yaitu memperoleh keuntungan untuk keberlanjutan dan pengembangan usaha. Berdasarkan temuan diatas penulis tertarik meneliti masalah ini dengan secara lebih dalam. Rumusan masalah dalam penelitian ini adalah Bagaimana kualitas pelayanan badan usaha milik desa melalui pelatihan administrasi program simpan pinjam pada Desa Selebung Batukliang Lombok Tengah.

Penelitian ini menggunakan pendekatan kualitatif deskriptif. Fokus dan tujuan penelitian ini adalah untuk mengetahui kualitas pelayanan Badan Usaha Milik Desa melalui pelatihan administrasi program simpan pinjam pada Desa Selebung Batukliang Lombok Tengah.

Jenis data yang digunakan dalam penelitian ini lebih banyak menggunakan data kualitatif berdasarkan hasil wawancara narasumber. Sumber Data yang digunakan: 1) data primer yaitu data yang diperoleh secara lansung dengan mengadakan wawancara langsung pada pengguna dana sebagai objek penelitian, 2) Data sekunder yaitu data yang diperoleh untuk memandingkan beberapa hal terkait penelitian, seperti jumlah pengguna, buku-buku diperpustakaan.

Teknik pengumpulan data menggunakan wawancara, dokumentasi, dan observasi dengan subyek penelitian yaitu Kepala Desa, Pengelola BUMDES, dan masyarakat penerima dampak BUMDes. Analisis data dalam penelitian ini menggunakan model analisis interaktif yaitu analisis dengan menggunakan reduksi data, display data, dan verifikasi dan kesimpulan

\section{HASIL DAN PEMBAHASAN}

Hasil penelitian ini menunjukan bahwa pelayanan BUMDes pada masyarakat Desa Selebung dengan melibatkan pengguna beberapa unsur masyarakat berdasarkan mata pencaharian (Tabel 1).

Tabel 1. Mata pencaharian Masyarakat Di Desa Selebung

\begin{tabular}{|c|l|c|}
\hline No & NamaPekerjaan & Jumlah (Orang) \\
\hline 1 & Petani pemilik & 704 \\
\hline 2 & BuruhTani & 892 \\
\hline 3 & Wiraswasta & 774 \\
\hline 4 & PNS & 62 \\
\hline 5 & Peternak & 34 \\
\hline
\end{tabular}

Sumber: Desa Selebung, 2017

BUMDes Desa Selebung memiliki berbagai jenis pelayanan yang diberikan menyangkut penanganan berbagai persoalan yang dihadapi oleh masyarakat pedesaan, dibidang ekonomi pedesaan dilayani melalui usaha simpan pinjam dan pertokoan, dengan harga yang dapat dijangkau oleh masyarakat. Di bidang konsumsi masyarakat, dalam pemenuhan kebutuhan pokok sehari-hari, bidang kesehatan dan pendidikan juga dapat dilayani melalui penyediaan kredit konsumtif, dan bantuan sosial bagi masyarakat tidak mampu.

Berdasarkan hasil wawancara mendalam dengan AGS (Kepala Desa Selebung) pada tanggal 21 April 2017 menyebutkan bahwa keberadaan BUMDes sangat membantu dalam pemberdayaan dalam meningkatkan kesejahteraan masyarakat sebagai pengguna program BUMDes bidang simpan pinjam. namun pada sisi pelayanan semakin lebih baik setelah dilakukan secara komputerisasi guna mendukung pelaksanaan kegiatan proses simpan pinjam.

Keberhasilan program simpan pinjam pada Desa Selebung diperkuat dari hasil penelitian Wijanarko(2013) menjelaskan bahwa upaya BUMDes dalam memberi pinjaman kepada anggota telah membantu untuk meningkatkan perekonomian masyarakat, hal ini tujuan BUMDes untuk mencapai kesejahteraan masyarakat telah tercapai.

Pernyataan Kepala Desa Selebung diperkuat dari hasil wawancara mendalam dengan FTH (Pengelola BUMDes) menyatakan bahwa BUMDes mampu memberikan kemudahan dalam mengembangkan usaha 
masyarakat dengan pemberian modal secara cepat, tepat dan bermanfaat. Oleh karena itu, pelayanan yang diberikan dengan pelayanan prima yang mampu memberikan kepuasan pada penerima manfaat program simpan pinjam.

Keberadaan BUMDes ini mampu memberikan manfaat pada masyarakat dengan visi dan misi utama adalah pelayanan prima mutlak diberikan kepada masyarakat. Artinya, tuntutan publik terhadap pelayanan prima merupakan keharusan yang tidak bisa diabaikan lagi oleh aparatur pemerintah karena hal ini merupakan bagian dan fungsi pemerintah dalam menjalankan tugas- tugas pemerintahan. Untuk mengetahui tingkat keberhasilan dalam melayani dan mewujudkan kepuasan masyarakat, maka perlu dikembangkan suatu mekanisme penilaian customer satisfaction atas pelayanan yang telah diberikan oleh penyelenggara pelayanan publik. Dalam konsep manajemen pelayanan, kepuasan pelanggan dapat dicapai apabila produk pelayanan yang diberikan oleh penyedia pelayanan memenuhi kualitas yang diharapkan masyarakat.

Pernyataan diatas mampu memberikan manfaat bagi masyarakat terhadap keberadaan BUMDes ditengah masyarakat. Pelaksanaan kegiatan BUMDES dilakukan dengan memperhatikan kriteria penerima pinjaman bumdes adalah dengan memperhatikan karakter seseorang, apakah orang tersebut memiliki kemauan untuk memenuhi kewajiban, kemauan untuk melunasi kewajiban dan melakukan penilaian terhadap suatu usaha dengan memperhatikan komposisi permodalannya. Sedangkan tata pelaksanaan proses pengajuan kredit adalah dengan mengisi blangko permohonan kredit yang dilengkapi dengan photo copy KK, KTP dan KPS yang ditandatangani oleh Kadus dan anggota BPD, dengan menerapkan struktur baku pelayanan baik dibidang kredit, usaha perdagangan dan air bersih. Setelah itu diverifikasi oleh tim kredit dari BUMDES. Setelah diverifikasi maka tinggal menunggu jadwal pencairannya.

Wawancara mendalam dengan $B Q$ (penerima Manfaat Program BUMDes) tanggal 21 April 2017 menyebutkan bahwa program BUMDes tentang simpan pinjam sangat bermanfaat sebagai penegmbangan modal usaha dan bisa menyekolahkan anak sekolah dan kuliah. Terhadap palayanan sudah cukup bagus dengan sistem komputerisasi memberikan pelayan lebih cepat dibandingkan dengan sistem manual dibutuhkan kami menunggu lama.

Temuan diatas memberikan arti bahwa dana BUMDes Desa Selebung yang diberikan berupa pinjaman sebagai modal usaha kepada masyarakat, khususnya masyarakat. Dana BUMDes Desa Selebung ini telah dapat memberikan peningkatan perekonomian masyarakat yang menjadi pengguna dan BUMDes diberbagai bidang usahayang sedang dijalankan masyarakat. Keberadaan usaha masyarakat ini sama - sama telah dirasakan adanya peningkatan pada pendapatannya sehingga dapat meningkatkan perekonomian masyarakat perdesaan.

Temuan tersebut diperkuat dengan hasil penelitian Ibrahim dkk (2017) menjelaskan bahwa keberdaan BUMDes belum mampu memberikan manfaat dalam meningkatkan kesejahteraan masyarakat. Hal ini karena minimnya Sumberdaya Manusia dan tata kelola yang tidak berkelanjutan. Sinergitas pengelola BUMDes dan masyarakat dalam partisipasi secara aktif dari dalam perencanaan, pelaksanaan hingga evaluasi guna memberikan manfaat keberadaan BUMDes ditengah masyarakat.

\section{SIMPULAN}

Penerapan pelatihan terhadap program simpan pinjam pada BUMDes menunjukan bahwa memberikan dampak positif dalam pengembangan usaha. Hal ini dibuktikan dari sebelumnya pengolahan admnistrasi masih bersifat administrasi manual dan berubah menggunakan komputerisasi dengan sistem yang teratur.

\section{DAFTAR RUJUKAN}

Ibrahim, Kamaluddin Dan Mistasrihardi, 2017, Persebaran Program Badan Usaha Milik Desa Di Kabupaten Sumbawa Barat, Prosiding, Seminar Nasional, UNS Surakarta

Ibrahim, Mintasrihardi, Achmad Djuanidi, 2017 Sinergisitas Program Badan Usaha Milik Desa Dalam Penanggulangan Kemiskinan Di Kabupaten Sumbawa Barat, Prosiding, Hasil Seminar Nasional, Universitas Negeri Malang

Nugroho, Rochim, 2004, Pembangunan Wilayah, Yogyakarta: Pustaka Jogja Mandiri

Prasetyo, Azis, Ratna, 2016, Peranan Bumdes Dalam Pembangunan Dan Pemberdayaan Masyarakat Di Desa Pejambon Kecamatan Sumberrejo Kabupaten Bojonegoro, Jurnal Dialektika, Vol. X1 No.1 Maret 2016, Hal: 86-100 
Sari, Lucita Dwi, 2015, Persepsi Masyarakat Terhadap Kinerja Aparatur Desa Dalam Meningkatkan Pelayanan Publik Di Desa Bumi Agung Marga Kecamatan Abung Timur Kabupaten Lampung Utara, Skripsi, Diakses Http://Digilib.Unila.Ac.Id/22404/3/S KRIPSI\%20TANPA\%20BAB\%20P EMBAHASAN.Pdf. Pada Tanggal 25 November 2017

Susanti, Luh dan Ardana Joni Made Dewa, 2016, Pelayanan Badan Usaha Milik Desa (BUMDES) "Sidi Amerta" di Desa Sangsit Kecamatan Sawan Kabupaten Buleleng, diakseshttp://locusfisipunipas.blogs pot.co.id/2016/11/pelayanan-

badan-usaha-milik-desabumdes 14.html pada tanggal 25 November 2017

Undang-Undang No. 32 Tahun 2004 Tentang Otonomi Daerah

Undang-Undang No. 6 Tahun 2014 Tentang Desa

Wijanarko, Agung Septian, 2013, Peran Badan Usaha Milik Desa (Bumdes) Dalam Pemberdayaan Masyarakat Di Desa Pandankrajan Kecamatan Kemlagi Kabupaten Mojokerto, Skripsi FISIP Universitas Pembangunan Nasional VETERAN Jawa Timur Surabaya 